\title{
THE BRITISH JOURNAL OF VENEREAL DISEASES
}

\section{ARSENICAL ENCEPHALOPATHY \\ A REVIEW OF THE LITERATURE WITH A REPORT OF A FURTHER 187. CASES}

\author{
By ERNEST E. PREBBLE, M.D.
}

Senior Assistant Venereal Diseases Medical Officer, Seamen's Dispensary; Assistant Venereal Diseases Medical Officer, Liverpool Royal Infirmary; Late Brigadier, Consultant Venereologist, India Command

Severe cerebral complications occurring during the treatment of syphilis with arsenical drugs have been considered, in the past, to be exceedingly rare. Recent experience in India suggests, however, that these complications are not nearly so rare as we have been led to suppose.

\section{Survey of the literature}

Time of onset.-The literature on this subject is extensive ; an attempt is made below to summarize a large number of reported cases. Among the earliest recorded cases are those published in the year 1911 by Fischer, by Kannengiesser and by Almkvist, each of whom describes one fatal case occurring after the intravenous injection of Salvarsan.

Fischer's patient was given 0.4 gramme of Salvarsan on 28th March 1911 with no untoward effects; a second similar injection was given on 6th May 1911. Two days later there was a gradual onset of symptoms proceeding to coma and death.

Kannengiesser's patient was given 0.5 gramme of Salvarsan on 28th April 1911 and no reaction followed its administration; a second injection was given on 11 th May with no immediate effect. Three days later there was a sudden onset of convulsions, followed shortly afterwards by coma and death.

Almkvist reported a case in which the patient was given 0.6 gramme of Salvarsan on 16th November 1911. Two days later the patient complained of headache ; on the following day the headache was much worse and was accompanied by vomiting, loss of memory and cyanosis. After an injection of camphor in oil his condition improved slightly; he was able to answer questions and to recognize people but was unaware of the day or the month. On 20th November his condition became much worse and deep coma ensued, followed by death 2 days later.

From this time onwards cases were reported by many observers. For convenience, these are summarized in three tables. Table 1 consists of cases reported as occurring after the administration of various arsenical compounds, given usually once weekly and in a few cases twice weekly. Table 2 shows those cases which have been reported as occurring during pregnancy, and Table 3 those reported as occurring in the course of various types of modern intensive arsenotherapy. It is inevitable that certain reported cases have not been mentioned, but the numbers given are sufficiently large to be of value. From Tables 1 and 2 the following facts emerge. In all, 75 cases are reported, of which 57 were fatal and 18 non-fatal. The onset of symptoms occurred after a varying number of injections of the arsenical preparation.

$\begin{array}{rr}\text { Injections given } & \text { Cases of encephalopathy } \\ \text { After 1st injection } & 2 \text { cases } \\ \text { " 2nd " } & 15, \\ \text { " 3rd " } & 14, \\ \text { " 4th " } & 2, " \\ \text { " 5th " } & 5, " \\ \text { "6th - " } & 2 \text { ", }\end{array}$

There was also a single case after each of the sixth, seventh, eleventh, fifteenth, and forty-fifth injections. 
The number of days after the first injection on which symptoms occurred were as under.

$\begin{array}{llll}\begin{array}{l}\text { Number } \\ \text { of days }\end{array} & \begin{array}{l}\text { Number } \\ \text { of cases }\end{array} & \begin{array}{l}\text { Number } \\ \text { of days }\end{array} & \begin{array}{l}\text { Number } \\ \text { of cases }\end{array} \\ 4 \text { th day } & 1 \text { case } & 12 \text { th day } & 1 \text { case } \\ \text { 6th day } & 1 \text { case } & 15 \text { th day } & 5 \text { cases } \\ \text { 8th day } & 1 \text { case } & 16 \text { th day } & 2 \text { cases } \\ 9 \text { th day } & 4 \text { cases } & 17 \text { th day } & 6 \text { cases } \\ \text { 10th day } & 5 \text { cases } & 22 \text { nd day } & 2 \text { cases } \\ 11 \text { th day } & 4 \text { cases } & 25 \text { th day } & 2 \text { cases }\end{array}$

There was also one case each day on the fortieth, forty-fifth, fifty-fourth, eighty-first and one-hundred-and-twenty-fifth days.

Clinical picture.-In 1919 the Salvarsan Committee ${ }^{1}$ of the Medical Research Council issued a report in which it was stated that "severe cerebral symptoms, characterised by intense headache, followed by epileptiform convulsions, coma and death, have been known to occur from one to five days after the administration of arsphenamine or neoarsphenamine. Fortunately these serious occurrences are very rare." In 1922, in a further report from the Salvarsan Committee ${ }^{2}$ discussing this condition, it was stated that it could occur after the administration of any arsenobenzol product and that it was most frequent after the second injection but could occur after a single injection. The clinical picture described is typical of some of the cases reported below in the present series. The commonest history was found to be as follows.

Intense headache is the initial symptom and may be accompanied by fever, shivering and vomiting. On the following day the patient suddenly has an epileptiform convulsion, with clonic spasms, followed by unconsciousness. The deep reflexes are lost; a positive Babinski's sign is present ; squint and various other signs indicative of involvement of the central neryous system may occur. Retention of urine is common. Epileptiform convulsions recur at intervals and coma continues until death. A fatal result often supervenes within $\mathbf{4 8}$ hours of the onset of symptoms.

That similar cases may occur in the absence of syphilis has been shown by Levinson and Sophir, who describe 5 cases of "fulminating encephalitis" of unknown origin with typical symptoms and pathological findings. Glaser, Imerman and Imerman also describe one non-fatal case which occurred 8 days after the injection of so small a dose as 01.5 gramme of neoarsphenamine, given to a patient with Vincent's angina, and a further non-fatal case which occurred 22 days after the giving of 4 injections of neoarsphenamine for a skin eruption of a non-syphilitic nature.

In Table 1 several cases appear to have shown a very long incubation period. Friedman and Shinefield describe 2 such cases, both in children.

(1) The first patient was given 0.005 gramme of sulpharsphenamine in ascending doses over a period of $2 \frac{1}{2}$ months until a total of 0.625 gramme had been given; 6 days after the last injection there was a gradual onset of symptoms with a fatal termination.

(2) The second patient was treated with Acetarsone (acetarsol) in ascending dosage until 20 milligrams of arsenic per kilogram of body weight had been administered, with a total dosage of $17 \cdot 7$ grammes over a period of 3 months. Sulpharsphenamine was then given once weekly without incident until $₹$ days after the seventh injection, when a gradual onset of symptoms occurred ; there was a fatal termination.

Tuta and Stagman describe a fatal case occurring during the third course of injections, in which the patient had received 2 complete courses of neoarsphenamine without incident and had started the third course with $0.3,0.45$, and 0.6 gramme of neoarsphenamine at weekly intervals ; 10 days after the third injection there was a gradual onset of symptoms and death supervened.

Brittingham and Phinizy also describe an unusual case. The patient was pregnant and received 5 injections of neoarsphenamine prior to her delivery. Three months later, after 


\section{ARSENICAL ENCEPHALOPATHY}

delivery, she reported for further treatment and was given 2 injections of 0.6 gramme of neoarsphenamine with an interval of one week between injections. Two days after the second injection (that is, 10 days after the commencement of the second course) there was a gradual onset of symptoms with a fatal termination.

TABLE 1-CASES OF ARSENICAL ENCEPHALOPATHY REPORTED IN THE LITERATURE

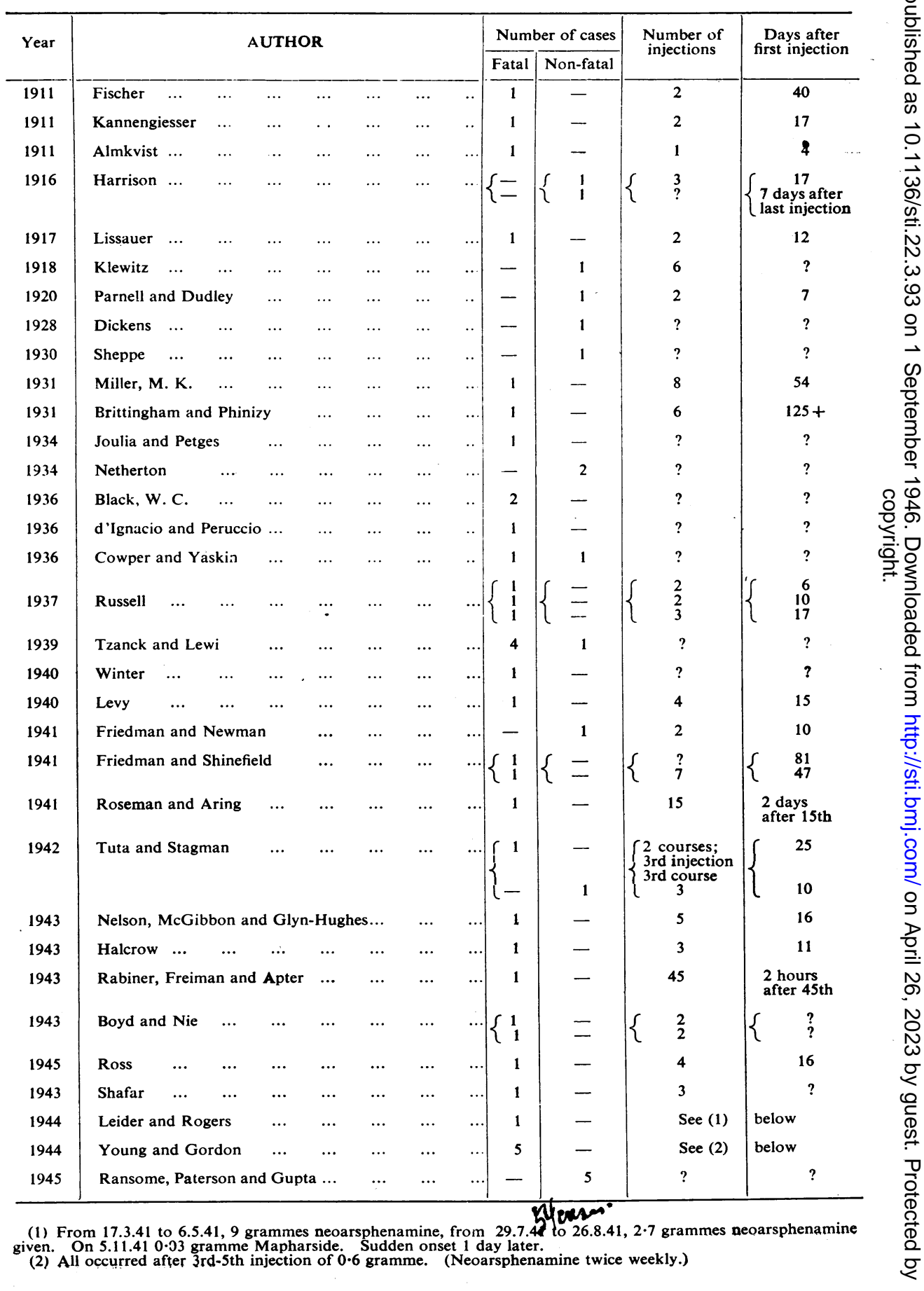




\section{THE BRITISH JOURNAL OF VENEREAL DISEASES}

Rabiner, Freiman and Apter describe a fatal case which occurred after 45 injections o Mapharside. The patient received 44 injections without incident and was given a period of 6 weeks' rest. Two hours after the forty-fifth injection there was a sudden onset of symptoms and the patient died 21 days later.

The last-mentioned case is most unusual, in that the onset occurred so late in the course of treatment and that the period between onset and death was of such long duration.

TABLE 2-CASES OCCURRING IN PREGNANCY REPORTED IN THE LITERATURE

\begin{tabular}{|c|c|c|c|c|c|c|c|c|c|c|}
\hline \multirow{2}{*}{ Year } & \multirow{2}{*}{\multicolumn{6}{|c|}{ AUTHOR }} & \multicolumn{2}{|c|}{ Number of cases } & \multirow{2}{*}{$\begin{array}{c}\text { Number of } \\
\text { injections }\end{array}$} & \multirow{2}{*}{$\begin{array}{l}\text { Days after } \\
\text { first injection }\end{array}$} \\
\hline & & & & & & & Fatal & Non-fatal & & \\
\hline 1916 & von Zumbusch $\ldots$ & $\ldots$ & $\ldots$ & $\cdots$ & $\cdots$ & $\cdots$ & 1 & - & 3 & 22 \\
\hline 1935 & Plass and Woods... & $\cdots$ & $\cdots$ & $\cdots$ & $\cdots$ & $\cdots$ & $\begin{array}{l}1 \\
1 \\
1\end{array}$ & $\left\{\begin{array}{l}- \\
-\end{array}\right.$ & $\begin{array}{l}5 \\
3 \\
3\end{array}$ & $\begin{array}{r}22 \\
8 \\
10\end{array}$ \\
\hline 1936 & Woods $\quad \ldots$ & $\ldots$ & $\ldots$ & $\because$ & $\ldots$ & $\ldots$ & 3 & - & $?$ & $?$ \\
\hline 1936 & Sawyer and Dwyer & $\cdots$ & $\ldots$ & ... & $\cdots$ & $\cdots$ & 1 & $\therefore-$ & $?$ & ? \\
\hline 1936 & Lanzenberg and Laug & & $\ldots$ & $\cdots$ & $\cdots$ & $\cdots$ & 1 & - & ? & $?$ \\
\hline 1936 & Cormia $\quad \ldots$ & $\ldots$ & $\ldots$ & $\ldots$ & ... & ... & 1 & - & 2 & 9 \\
\hline 1938 & Kuehn, Keatinge and & von & am & $\cdots$ & $\cdots$ & $\cdots$ & $\begin{array}{l}1 \\
1\end{array}$ & 二 & $\begin{array}{l}1 \\
3\end{array}$ & $\begin{array}{r}9 \\
17\end{array}$ \\
\hline 1939 & Paley and Pleshette & $\cdots$ & ... & $\cdots$ & $\cdots$ & $\cdots$ & 1 & 一 & 11 & 45 \\
\hline 1939 & Ingraham... & $\cdots$ & $\cdots$ & $\cdots$ & $\cdots$ & $\cdots$ & $\left\{\begin{array}{l}1 \\
1 \\
1\end{array}\right.$ & E & $\begin{array}{l}2 \\
2 \\
2\end{array}$ & $\begin{array}{r}11 \\
15 \\
9\end{array}$ \\
\hline 1942 & Arnell and Guerriero & $\cdots$ & $\cdots$ & $\cdots$ & $\cdots$ & $\cdots$ & $\left\{\begin{array}{l}1 \\
1\end{array}\right.$ & - & $\ddot{3}$ & $\begin{array}{l}25 \\
11\end{array}$ \\
\hline 1943 & Nelson, McGibbon a & a $G$ & -Hug & es... & $\cdots$ & $\cdots$ & $\left\{\begin{array}{l}1 \\
1 \\
-\end{array}\right.$ & 二 & $\begin{array}{l}2 \\
3 \\
3\end{array}$ & $\begin{array}{r}10 \\
9 \\
11\end{array}$ \\
\hline
\end{tabular}

\section{1}

Relative incidence of encephalopathy.-Various authors have attempted to assess the incidence of this serious complication.

Cole and his colleagues describe 6 fatal cases out of 1,212 patients treated $(1: 202)$; on the other hand, Milian and Brodier state that the condition occurred only 4 times in 27 years' experience in a large hospital. Cook reported 63 deaths from arsphenamine in the United States Navy from 1919 to 1935 . In 21 of 23 autopsies he found brain damage ; in 21 other autopsies the brain was not examined, but many of these patients had shown signs of encephalitis before death.

Incidence of fatalities.-Laurent reported 2 fatalities out of 2,800 patients treated, whereas McCord, on the other hand, states: "With an experience of many thousands of doses of all kinds of arsenical preparations given to pregnant women, I have never seen a reaction that approaches a fatality; I rarely see a 'reaction of any kind.'

Friedman and Shinefield found 65 cases in the literature from 1925 to 1939 , of which 54 were cases of syphilis and 11 were non-syphilitic ; 51 of these patients died and 14 recovered. Smith and Newbill found 175 cases reported in the literature up to 1939, and so did Friedman and Newman up to 1941, whereas Paley and Pleshette, writing in 1939, enumerated 158 cases, almost all fatal, and observed that 70 per cent of all cases occurring in females were associated with pregnancy.

Type of onset.-Tzanck and Lewi describe 3 types of onset of symptoms, which they classify as under.

(1) Severe.-In these there is no prodromal period and onset of coma is rapid.

(2) Mild.- In these, convulsions occur without coma and there is occasionally hemiplegia or monoplegia.

(3) Abortive. - In these the main symptoms are mental disturbances, such as confusion, disorientation, amnesia and aphasia. 
In my own series, cases have been divided into those with a gradual onset similar to that of the abortive type and those with a sudden onset and without prodromal symptoms, a similar grouping to the severe and mild types described by Tzanck and Lewi. Since the adoption of the use of neoarsphenamine and Mapharside in intensive methods of treatment, arsenical encephalopathy has received rather more prominence in the literature, as is indicated in Table 3. This may be explained, perhaps, by the fact that all these cases received in-patient treatment and were therefore under constant observation by experts. Out of 12,333 patients so treated, symptoms of encephalopathy developed in 109 cases with a fatal termination in 46 cases ( 42 per cent) and recovery in 63 cases. The incidence is therefore $1: 113$, and the incidence of fatal cases $1: 268$. (These figures do not include 3 patients who recovered and in regard to whom the total number of patients treated was not given.)

From Tables 1, 2 and 3 we thus have 187 cases, with 103 fatalities and 84 recoveries, giving a total fatality rate of 55 per cent.

TABLE 3-CASES OCCURRING AFTER INTENSIVE ARSENOTHERAPY REPORTED IN THE LITERATURE

\begin{tabular}{|c|c|c|c|c|}
\hline Year & \multicolumn{3}{|c|}{ AUTHOR } & OBSER VATIONS \\
\hline 1939 & \multicolumn{2}{|l|}{ Hyman and others } & $\cdots$ & Mapharside. 2 cases with one fatality out of 86 patients treated. \\
\hline 1941 & Rattner & $\ldots$ & $\cdots$ & 2 cases with recovery out of 65 patients treated. \\
\hline 1941 & Elliott and others & $\ldots$ & $\ldots$ & $\begin{array}{l}\text { Series } 1.502 \text { patients. Mild cerebral reaction in } 38 \% \text {; fatal cases- } \\
0.2 \% \text { recoveries - } 0.6 \% \\
\text { Series } 2.466 \text { patients. Mild cerebral reaction in } 23.2 \% \text {; fatal cases- } \\
0.4 \% \text {, recoveries-0.4\%. In } 1,600 \text { patients treated they found } 5 \text { deaths. }\end{array}$ \\
\hline 1941 & \multicolumn{3}{|c|}{ Leifer, Chargin and Hyman } & $\begin{array}{l}\text { Series } 1 .-111 \text { patients ; neoarsphenamine. In } 1.8 \% \text { of cases symptoms } \\
\text { developed ; 1 death occurred. } \\
\text { Series 2. } 275 \text { patients; Mapharside. In } 1 \cdot 1 \% \text { of cases symptoms } \\
\text { developed, but recovery ensued. Total: } 5 \text { cases with } 1 \text { death. }\end{array}$ \\
\hline 1942 & Chana & $\cdots$ & $\cdots$ & $\begin{array}{l}1,300 \text { patients treated; } 12 \text { fatalities. They also observed } 2 \text { severe but } \\
\text { non-fatal cases in one month. }\end{array}$ \\
\hline 1942 & \multicolumn{3}{|c|}{ Schoch and Alexander } & 3 cases with 1 death out of 350 patients treated with Mapharside. \\
\hline 1942 & \multicolumn{3}{|c|}{ Thomas, Wesler and Dattner } & 8 cases with 2 deaths out of 764 patients treated. \\
\hline 1943 & Boyd and Nie & $\cdots$ & $\cdots$ & 2 non-fatal cases after intensive Mapharside treatment. \\
\hline 1944 & \multicolumn{2}{|l|}{ Young and Gordon } & $\cdots$ & 1 non-fatal case after neoarsphenamine. \\
\hline 1944 & Lydon & $\cdots$ & $\cdots$ & 5 cases with 1 fatality out of 53 patients treated with Mapharside. \\
\hline 1944 & Cannon and others & & $\cdots$ & 2 non-fatal cases out of 362 patients treated intensively with arsphenamine. \\
\hline 1944 & Thomas and Wexle & & $\ldots$ & $\begin{array}{l}\text { Series } 1 .-321 \text { patients receiving Mapharside; } 5 \text { cases with } 1 \text { death. } \\
\text { Series } 2 .-588 \text { patients; Mapharside with fever therapy ; } 8 \text { cases with } 2 \\
\text { deaths. } \\
\text { Series } 3 .-1,181 \text { patients. 10-day Mapharside with bismuth and fever } \\
\text { therapy; } 4 \text { cases with } 1 \text { death. }\end{array}$ \\
\hline 1944 & Curtis & $\cdots$ & $\cdots$ & Out of 58 patients, 7 cases with 2 deaths. \\
\hline 1944 & Cole and others & & $\ldots$ & $\begin{array}{l}4,351 \text { patients treated. Incidence }: 7 \cdot 1 \text { per thousand patients with } 3 \cdot 2 \\
\text { per thousand fatal. }\end{array}$ \\
\hline
\end{tabular}

\section{Pathology of arsenical encephalopathy}

The pathological changes found in arsenical encephalopathy have been described by a considerable number of investigators. Baker examined histologically a series of 20 cases and found that if death occurred within 24 hours haemorrhages alone were present in the brain. In cases with longer survival he found increasing degrees of perivascular demyelination, associated, in the more advanced stages, with an infiltration by macrophages of the demyelinated areas, and he was able to distinguish clearly between haemorrhagic and non-haemorrhagic perivascular lesions. Cormia found in the cerebral cortex of the temporal lobe intense engorgement of the capillaries, with erythrocytes and leucocytes and extensive focal perivascular extravasations. In places he found a narrow zone of necrosis surrounding a central thrombosed capillary, most of the areas displaying ring 
haemorrhages. In the cerebral cortex of the frontal lobe scattered thrombi were found, with marked vacuolation, swelling and fragmentation of the glial fibres. Capillary thrombosis was also present in the thalamus, and the lentiform and caudate nuclei showed intense engorgement of the larger arteries and veins. The

TABLE 4-PATHOLOGICAL FINDINGS RECORDED IN THE LITERATURE

\begin{tabular}{|c|c|c|c|c|}
\hline Year & \multicolumn{3}{|c|}{ AUTHOR } & FINDINGS \\
\hline 1911 & Almkvist $\ldots$ & $\ldots$ & $\cdots$ & Punctiform haemorrhages in brain \\
\hline 1911 & Kannengiesser & $\cdots$ & $\cdots$ & Haemorrhagic and non-haemorrohgic areas with hyaline degeneration \\
\hline 1911 & Fischer & $\cdots$ & $\cdots$ & Ring haemorrhages in basạl ganglia \\
\hline 1912 & v.Marschalko an & d Ves & prémi & $\begin{array}{l}\text { Numerous small haemorrhages, consisting of erythrocytes; no signs of } \\
\text { breaking down of brain cells nor evidence of softening; one group of } \\
\text { brain capillaries was found to be entirely filled with hyaline thrombi }\end{array}$ \\
\hline 1912 & Busse and Meria & & $\cdots$ & Necrotic non-haemorrhagic areas in the brain \\
\hline 1913 & Schmorl & $\cdots$ & $\cdots$ & Softened areas in the brain \\
\hline 1913 & Pollak and Riehl & & $\cdots$ & Necrotic areas and haemorrhagic perivascular lesions in the brain \\
\hline 1917 & Lissauer & $\cdots$ & $\cdots$ & $\begin{array}{l}\text { Abundant small perivascular haemorrhages; thrombi in some capillaries } \\
\text { surrounded by small necrotic areas }\end{array}$ \\
\hline 1925 & Levinson and So & phir & $\cdots$ & $\begin{array}{l}\text { Perivascular infiltration with neutrophils and lymphocytes, and haemorr- } \\
\text { hage in perivascular spaces; a few erythrocytes in parenchyma but } \\
\text { no ring haemorrhages }\end{array}$ \\
\hline 1925 & Miller, J. ... & $\cdots$ & $\cdots$ & $\begin{array}{l}\text { Massive cerebral haemorrhages as well as petechial haemorrhages; hyaline } \\
\text { changes in vessel walls; thrombosis of vessels with perivascular } \\
\text { infiltration }\end{array}$ \\
\hline 1928 & Alpers & $\cdots$ & $\cdots$ & $\begin{array}{l}\text { Non-haemorrhagic areas of perivascular necrosis, about which cells were } \\
\text { collected in a palisade-like formation, which he identified as an } \\
\text { oligodendroglia }\end{array}$ \\
\hline 1931 & Miller, A. K. & $\ldots$ & $\cdots$ & $\begin{array}{l}\text { Petechial and punctate areas of haemorrhage ; perivascular hæmorrhage } \\
\text { with leucocytic infiltration }\end{array}$ \\
\hline 1935 & Plass and Woods & & $\cdots$ & $\begin{array}{l}\text { Oedema and small haemorrhages in brain and cord ; punctate extravasa- } \\
\text { tion of blood around the capillaries ; hyaline thrombosis of capillaries }\end{array}$ \\
\hline 1936 & Wolff & $\cdots$ & $\cdots$ & $\begin{array}{l}\text { Demyelination and aggregation of phagocytes taking place at centres of } \\
\text { ring haemorrhages; erythrocytes persisting there for some days }\end{array}$ \\
\hline 1939 & Paley and Pleshe & & $\cdots$ & $\begin{array}{l}\text { Circular and ovoid haemorrhagic areas under the ependyma; in one area } \\
\text { leucocytes and hyaline thrombi present in some of smaller vessels }\end{array}$ \\
\hline 1942 & Arnell and Gue & & $\cdots$ & Pericapillary changes in the brain ; extremely marked haemorrhage in pons \\
\hline 1942 & Tuta and Stagma & & $\cdots$ & Numerous small pin-point haemorrhages, chiefly in white matter \\
\hline 1943 & Rabiner, Freimar & and & pter & $\begin{array}{l}\text { Stasis, oedema, petechial haemorrhages ; degeneration and gliosis ; } \\
\text { occasional ring haemorrhages seen. Lesions of a necrotic type, } \\
\text { generally small and confined to grey matter, were prominent }\end{array}$ \\
\hline 1943 & Boyd and Nie & $\cdots$ & $\cdots$ & $\begin{array}{l}\text { Vascular congestion and stasis ; oedema ; focal necrosis; capillary } \\
\text { haemorrhages throughout the white matter }\end{array}$ \\
\hline 1943 & Shafar & $\cdots$ & $\cdots$ & $\begin{array}{l}\text { Perivascular areas of necrosis ; no ring haemorrhages but a few erythro- } \\
\text { cytes present in necrotic areas }\end{array}$ \\
\hline 1944 & Scheinker $\ldots$ & $\ldots$ & $\ldots$ & $\begin{array}{l}\text { Minute punctate haemorrhages, chiefly in white matter ; petechial } \\
\text { perivascular haemorrhages filling the perivascular spaces; ring hæmorr- } \\
\text { hages with haemorrhagic infiltration of tissue adjacent to vessel. A } \\
\text { series of non-haemorrhagic lesions seen in nerve parenchyma adjacent } \\
\text { to smaller vessels }\end{array}$ \\
\hline 1942 & Courville and $\mathrm{M}$ & Irsh & $\ldots$ & $\begin{array}{l}\text { Multiple symmetrical foci of haemorrhagic necrosis. Petechiz scattered } \\
\text { throughout the white matter. Tendency for haemorrhagic foci to } \\
\text { localize in regions of both grey and white matter of brain. The } \\
\text { corpus callosum, thalami, external capsule and frontal and parieto- } \\
\text { occipital centra apparently sites of special predilection }\end{array}$ \\
\hline
\end{tabular}

pons showed intense engorgement of the capillaries with slight vacuolation of pale-staining glial cells; in the medulla there were numerous capillary thrombi with swollen endothelial cells. An excellent description is given by Dorothy Russell, who lays particular stress on the presence of non-haemorrhagic areas of perivascular necrosis wth demyelination, in addition to haemorrhagic areas; she 
suggests that the former represent a less intense reaction on the part of the tissues. She states that the most conspicuous lesions are perivascular, often ring-shaped, haemorrhages. There are also non-haemorrhagic perivascular lesions, which may be found near the haemorrhages or remote from them, often consisting simply of a perivascular zone of necrosis without infiltrating cells. Great swelling of the axis cylinders is found, accompanied by ballooning, thinning and disintegration of the myelin sheaths and by a fatty degeneration of the capillary endothelium in both cortex and white matter of the left excitomotor area. Kuehn, Keating and von Haam describe small petechial haemorrhages, which they found scattered throughout the entire brain but particularly in the pons, with extensive destruction of nerve substance by confluent and profuse haemorrhages. The vessels were dilated and hyperaemic, and the perivascular spaces were filled with blood which had penetrated in the form of fine streaks into the surrounding nervous tissue. Infiltration with leucocytes was not seen. The ganglionic cells of the cortex were slightly swollen with deep-purple-staining protoplasm. Roseman and Aring also stress the presence of non-haemorrhagic areas of necrosis; they state that the most important lesions in the nervous system were focal perivascular areas of necrosis unrelated to haemorrhage but related to changes in the small blood vessels, chiefly of the endothelium, which not infrequently occluded the vessel. Petechial haemorrhages, which probably occurred simultaneously to but apart from the perivascular necrosis, did not seem (in the authors' opinion) to be important in the analysis of the lesions of the disease. The views of numerous other observers are tabulated in Table 4 for easy reference.

\section{Theories concerning causation}

Many theories about the causation of this complication have been expounded and these have been summarized by Raiziss and Koppelman, as under.

(1) Individual idiosyncrasy or sensitivity.

(2) Toxicity of the arsenical compound.

(3) Errors in administration.

(4) Too large a dosage.

(5) Herxheimer reaction.

(6) Chronic arterial disease.

(7) Liver or adrenal insufficiency.

(8) Disturbance in colloidal equilibrium of the blood.

(9) Direct toxic action on the brain capillaries.

(1) Individual idiosyncrasy or sensitivity.-The Salvarsan Committee ${ }^{2}$ believes encephalopathy to be a direct result of the arsenical compound, possibly in persons unduly susceptible ; this view is supported by Halcrow. Friedman and Shinefield suggest that the cause may be delayed metabolism of arsenic, due to hepatic insufficiency and to accumulation in the body of toxic products of the drug because of renal dysfunction; thus hypersensitivity to arsenic and its metabolites results, and the patient dies an anaphylactoid death when a further injection is given ; they admit, however, that in many cases there was no evidence of hepatic or renal dysfunction during life and that no abnormalities were found post mortem. One of the arguments against such a view is that cases occur after a single injection as well as after a number of injections.

That sensitivity can be produced has been demonstrated by Landsteiner and Jacobs, who succeeded in sensitizing guineapigs by the repeated intracutaneous injection of arsphenamine. After the second injection a pronounced local reaction with necrosis was obtained. In another experiment, guineapigs were given 2 intracutaneous injections of arsphenamine at an interval of 1 month and an intravenous injection of arsphenamine 3 weeks later ; 30 out of 50 animals died after typical anaphylactic reactions and others showed distinct symptoms of anaphylaxis. Moriyama, using patients serum, was able to transfer arsenical sensitivity to guineapigs, and this work was performed also by von Sulzberger.

On the other hand, Gjessing states that hypersensitivity, if responsible, is not permanent; he describes the case of a patient who recovered from arsenical encephalopathy and 6 weeks later received further treatment with neoarsphenamine. Lees holds the same views and describes a case in which treatment with intramuscular arsenic was resumed after recovery from encephalopathy. In my 
owń Indian series, described below, a patient (case 3) received a dose of an arsenical after recovery, without ill effects.

(2) Toxicity of the arsenical compound.-Stokes believes the condition to be directly due to the arsphenamine, but this view is not supported by Glaser, Imerman and Imerman, who state that it is not related either to the quantity of the drug given, to the number of injections or to the toxicity of the drug itself. This latter view would appear to be the correct one, as evidenced by M. K. Miller's case, in which 2 sisters were given injections from the same ampoule of sulpharsphenamine ; a fatal encephalopathy developed in one and in the other there was no untoward reaction. Similar evidence is provided by Leider and Rogers, who report a fatal case in which the patient was given an injection of Mapharside out of a bulk ampoule, 9 other patients also receiving the same substance without any ill effects.

(3) Errors in administration.-No cases can be found in the literature which would support this view.

(4) Too large a dosage.-Cormia supports this view in describing a fatal case in pregnancy, but his patient received only 2 injections of neoarsphenamine, of 0.3 and 0.45 gramme respectively, with an interval of one $\cdot$ week between injections. Glaser, Imerman and Imerman, (also Nelson, McGibbon and Glyn-Hughes) state that quantitative dosage does not play a large part ; this view is borne out by the fact that arsenical encephalopathy has occurred after a dose of 0.15 gramme in adults of normal physique.

(5) Herxheimer reaction.-The Salvarsan Committee ${ }^{2}$ expresses the opinion that the condition is really an acute cerebral syphilis, intensified as a result of the injection, but they do not bring evidence which really supports this view. Stokes does not subscribe to this theory, pointing out that the majority of Herxheimer effects occur after the first injection. Globus and Ginsburg (as well as Glaser, Imerman and Imerman) draw attention to the fact that the condition has occurred in non-syphilitic patients who have received arsenical treatment for other conditions.

(6) Chronic arterial disease ; (7) hepatic or adrenal insufficiency; (8) disturbance in the colloidal equilibrium of the blood.-No references can be found to support these theories.

(9) Direct toxic action on the brain capillaries.-Petersen and Hughes showed experimentally that arsenic in large dosage may cause increased capillary permeability. Siengalewiez found increased permeability of the brain capillaries in rabbits which had received intravenous injections of trypan blue and were then poisoned with arsphenamine. The trypan blue escaped into and stained diffusely the white matter about the lateral ventricles, the regions most commonly involved in arsenical encephalopathy. Osterberg cites cases of arsenical poisoning, due to the ingestion of considerable amounts of inorganic arsenic, in which no brain haemorrhages were found although the arsenic content of the brain was high. He states that the degree of concentration of arsenic in the organs is extremely variable, not only in different tissues but in the same tissues in different individuals, and that it is difficult to set any numerical value for the concentration of arsenic above which it can be stated with certainty that a pathological change is likely to ensue.

-Montgormery has attempted to answer this objection; he considers that amounts greater than 0.0097 per cent in the skin or hair, and greater than 1 milligram per litre in the urine, may be of pathological significance. Osterberg and Kernohan have shown by chemical analysis that the arsenic content of the brain in cases of arsenical encephalopathy is lower than in cases in which death has been due to poisoning by inorganic arsenic ; they state that arsenical encephalopathy is not a recognized complication of poisoning with inorganic arsenic. In our own series of cases described below, D. Black found at necropsy that more arsenic was present in the brain of a patient who had died from encephalopathy than in that of a patient who had been undergoing antisyphilitic treatment before death but whose death was due to an unrelated condition. The actual amounts were 0.01 gramme per 100 grammes of brain tissue in the control and $0 \cdot 1$ gramme per 100 


\section{ARSENICAL ENCEPHALOPATHY}

grammes of brain tissue in the fatal case of encephalopathy. Nelson, McGibbon and Glyn-Hughes believe that the postmortem findings in their cases support the theory of direct toxic action on the brain capillaries; Winter, too, suggests that this is a likely cause, in view of the fact that in his case there was an associated purpura.

Other observations.-Various other writers have made observations on factors which may possibly have some bearing on the causation of this condition. Among the earliest references in the literature, Kerl, Obermiller, Tomasczewski, and Mentberger are all of the opinion that the particular variety of arsenobenzol (arsphenamine) used is without influence. Anoxaemia as a possible cause is suggested by Parnell and Dudley. In the present series of cases Byrne suggested that the condition was the result of interference with tissue respiration. Cole and his co-workers found the condition to be less common among coloured women patients than in white patients. Lydon suggests that alcoholism and vitamin B deficiency may be predisposing factors.

An interesting theory is put forward by Plass and Woods, who found the Wassermann reaction to be positive in the cerebrospinal fluid in 2 of their cases and suggest that such cases are especially predisposed to this reaction. It is interesting to note that Eapen investigated a series of 16 out of 21 cases (included in the present series) and found that 5 had a positive cerebrospinal and 11 a negative cerebrospinal fluid reaction; the remaining 5 patients were not subjected to such an examination. From this finding he drew the independent conclusion that a positive Wassermann reaction in the cerebrospinal fluid might be a possible predisposing factor.

Klaften, Pritzi, and Ireland are all of the opinion that young adults are most susceptible, women more so than men. This conclusion is rather to be expected when it is remembered that syphilis is most commonly acquired by young adults in the period of greatest sexual activity. Ireland states (as do Phelps and Washburn) that the danger is greater early in the course of treatment, encephalopathy occurring commonly after 1-4 injections; this is borne out amply by the published cases. Many writers stress the fact that pregnancy adds considerably to the risk of such a disaster.

Analysis of theories of causation.-Tzanck and Lewi write at some length on the various theories, as follows.

(1) Direct biotropism.-This is the Herxheimer reaction. It does not resemble true arsenical encephalopathy and is always cured by continuation of treatment.

(2) Indirect biotropism.-Milian's hypothesis states that arsenical treatment may reactivate spirochaetes, thus causing a skin eruption accompanied by encephalopathy. This condition, however, is slower in development and the paralytic lesions are inconstant in occurrence, as compared with arsenical encephalopathy.

(3) Intoxication.-This is very unlikely, seeing that arsenical encephalopathy occurs early after a small dose of the drug.

(4) Individual reactions.-(a) Nature of the reactogen (active fragment of the compound). Atoxyl (sodium $p$-aminophenylarsonate), Treparsol (formyl- $m$-amino- $p$-oxyphenylarsonate), Stovarsol (acetarsol), Acetylarsan (diethylamine acetarsol) neoarsphenamine, arsphenamine, Arsaminol (a Japanese arsphenamine) and Sulpharsenol (sulpharsenamine) all have the amino group in the meta position in their chemical structure. These compounds cause arsenical encephalopathy.

(b) Terrain. It is impossible to define exactly individual predisposition. Some authors have blamed adrenal insufficiency, whereas, according to another theory there is an imbalance in the vagosympathetic nervous mechanism in persons prone to reactions to arsenicals.

(c) Clinical picture. Encephalopathy may be the only finding, but it is sometimes accompanied by hepatitis, nephritis and skin eruptions.

(d) Physio-pathological mechanism. The experimental studies of Reilly point to an important role of the autonomic nervous system in the pathogenesis of this condition.

The remainder of this article, together with the list of references, will be published in the December number of the-Journal. 